\title{
Jesus: The infected healer and infectious community - Liminality and creative rituals in the Jesus community in view of COVID-19
}

\begin{tabular}{|c|c|}
\hline \multicolumn{2}{|c|}{$\begin{array}{l}\text { Author: } \\
\text { Zorodzai Dube }{ }^{1}\end{array}$} \\
\hline \multicolumn{2}{|c|}{$\begin{array}{l}\text { Affiliation: } \\
{ }^{1} \text { Department of New } \\
\text { Testament, Faculty of } \\
\text { Theology and Religion, } \\
\text { University of Pretoria, } \\
\text { Pretoria, South Africa }\end{array}$} \\
\hline \multicolumn{2}{|c|}{$\begin{array}{l}\text { Research Project Registration: } \\
\text { Project Leader: Z. Dube } \\
\text { Project Number: } 13339746\end{array}$} \\
\hline \multicolumn{2}{|c|}{$\begin{array}{l}\text { Description: } \\
\text { This research is part of the } \\
\text { project, 'Healing during th } \\
\text { New Testament', directed } \\
\text { Dr Dube, Department of N } \\
\text { Testament and Related } \\
\text { Literature, Faculty of } \\
\text { Theology and Religion, } \\
\text { University of Pretoria. }\end{array}$} \\
\hline \multicolumn{2}{|c|}{$\begin{array}{l}\text { Corresponding author: } \\
\text { Zorodzai Dube, } \\
\text { zoro.dube@up.ac.za }\end{array}$} \\
\hline \multicolumn{2}{|c|}{$\begin{array}{l}\text { Dates: } \\
\text { Received: } 08 \text { June } 2020 \\
\text { Accepted: } 05 \text { Sept. } 2020 \\
\text { Published: } 24 \text { Nov. } 2020\end{array}$} \\
\hline \multicolumn{2}{|c|}{$\begin{array}{l}\text { How to cite this article: } \\
\text { Dube, Z., 2020, 'Jesus: The } \\
\text { infected healer and infectious } \\
\text { community - Liminality and } \\
\text { creative rituals in the Jesus } \\
\text { community in view of } \\
\text { COVID-19', HTS Teologiese } \\
\text { Studies/Theological Studies } \\
76(1) \text {, a6189. https://doi. } \\
\text { org/10.4102/hts.v76i1.6189 }\end{array}$} \\
\hline \multicolumn{2}{|c|}{$\begin{array}{l}\text { Copyright: } \\
\text { C 2020. The Authors. } \\
\text { Licensee: AOSIS. This work } \\
\text { is licensed under the } \\
\text { Creative Commons } \\
\text { Attribution License. }\end{array}$} \\
\hline \multicolumn{2}{|l|}{ Read online: } \\
\hline 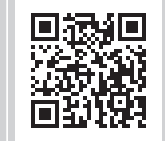 & $\begin{array}{l}\text { Scan this QR } \\
\text { code with your } \\
\text { smart phone or } \\
\text { mobile device } \\
\text { to read online. }\end{array}$ \\
\hline
\end{tabular}

Using theories in medical anthropology, especially the ideas inspired by Hector Avalos and George Foster, the study explains three activities associated with the early Christian healthcare system: (1) touching infectious people, (2) hospitality towards possibly infectious people and (3) the practice of itinerary evangelism as an activity that earned Christianity the dubious role of being a carrier of infectious diseases. Discussed alongside the issues associated with the advent of COVID-19, the study aims at (1) reflecting that early Christian healthcare system, which was an offshoot of Jewish healthcare systems, had practices that were perceived to exacerbate infection. In addition, (2) in view of the advent of COVID-19 pandemic, although of lesser catastrophe to ancient plagues, the study proposes that such epidemics call upon the collective actions of mercy and kindness, as Jesus did towards the infected. Theoretically, Victor Turner's concepts of liminality and communitas assist in imagining the discursive ideas concerning labelling and marginalisation of the Jesus movement, with comparative implication towards those suspected to have contracted the deadly COVID-19 virus. The study concludes with a warning against Christian practices that may further inflame infection by suggesting alternative practices for love and empathy towards others.

Contribution: Using ideas concerning infectious diseases in antiquity, the study reinterprets the Jesus movement as a movement that was perceived as carriers of infectious disease. Due to fear of infectious diseases, the rituals associated with hospitality towards the outsiders, the touch and laying of hands and iternary lifestyle were seen as promoting infection. Taking this perspective, the Jesus movement whose modus operandi is mostly associated with the periphery of the villages and cities created alternative rituals for the outcast. In view of the spread of COVID19, such stance by the Jesus movement provides lessons for the church and society to reach out to people who are considered infectious and burden to main society.

Keywords: COVID-19; marginalisation; infection; Jewish healthcare; labelling; communitas.

\section{Introduction}

The outbreak of COVID-19 (Coronavirus), a mutated coronavirus, started with the gossip of a deadly disease on the horizon, which suddenly became a reality. So far, across the globe, it has killed several people and subsequently caused the shutting down of local and global economies. Whilst the globe is still waiting for the vaccine, the prevalence of COVID-19 opened up discussions concerning the problem of inequality. Seemingly and statistically, those who are more vulnerable to the disease are the poor - those without proper housing, those that use public transport and those that do not have the extra income to maintain a high level of hygiene. From the daily instructions issued by the South African government, it is evident that COVID-19 requires a particular social and cultural infrastructure, for example, the use of particular hand sanitisers and the wearing of masks. Concerning infrastructure for quick recovery, an infected household member is supposed to be quarantined and fed with wholesome food. Given that most families sleep in small and crowded makeshift shelters, they do not have the option of keeping safe distance. Whilst the South African government banned and restricted the use of public transport under lockdown level 5, the opening up of business under lockdown 3 witnessed skyrocketing figures of those infected by the virus. Important to this study is the realisation that the poor, the unemployed and those without proper housing are at higher risk to contract and spread the infection. At the onset of the news about the virus, fearing the catastrophe that might be caused by COVID-19, Melinda Gates, the wife of the philanthropists Bill Gates, remarks saying: 
Covid-19 will be horrible in the developing world, she said. My heart is in Africa. I am worried. The only reason why the reported cases of the coronavirus disease in Africa is low now is most likely because there have not been wide testing of people. The disease is going to bite hard on the continent. I see dead bodies in the streets of Africa. (Bwire 2020:online)

Melinda Gate's comment is shared by many who understand the consequences because of the virus and the poverty levels in most African communities.

In this study, I do not wish to call for a more loving and caring society after the model of Jesus. I hope many within the various religious traditions have already done so. Using examples from ancient Greco-Roman society and the New Testament, it is evident that the Jesus movement started and spread during a period in history that was associated with daily fear of infectious diseases, many of whom had much deadlier results than COVID-19. For example, as we shall see, most ancient plagues, as they were labelled, wiped away villages and cities. Their presence meant one thing - awful smell of rotting human and animal bodies. Amongst the New Testament scholars, the general perception of the Jesus movement was that of a loving and caring gathering, vis-àvis the seemingly curious, Jewish healthcare system. Whilst this is true, it does not explain the entire picture: that is, Christianity was accused of exacerbating the cases of infection by welcoming the people whom the Jewish worldview had labelled as infectious. In this brief discussion, the task is (1) defining and illustrating various deadly infections and their consequences and (2) explaining the rise of Christian healthcare system and highlighting its modus operandi of itinerary evangelism, welcoming possibly infectious people and touching infectious people. Illustrated with select New Testament passages and fully cognisant of the fear of infection, I demonstrate how Christian healthcare system was sometimes even rejected and shunned for fear of spreading infectious diseases.

\section{What is infection or infectious diseases?}

We should start by defining and understanding the concepts of our discussion. Thus, for risking conflating modern terminology regarding disease aetiology to an ancient context, we need to define and put into perspective our discussion. In Greco-Roman cultures, there was no usage of the terms such as 'infection' or 'infectious'. Equally, there was no knowledge or concept of virus or bacteria. Instead, terms such as pandemic and plague were used to refer to the great catastrophes associated with certain sicknesses. Nowadays, the term 'infection' is mostly used in academic studies associated with epidemiology or immunisation to refer to the ability of a disease to replicate and infect several people (John \& Samuel 2000:601). As mentioned, during ancient Greco-Roman times, historians such as Livy (59 BCE) and modern medical historians such as Vivian Nutton used the terms such as 'epidemics' or 'plagues'. The contextual meaning suggests that a plague or epidemic was associated with sickness at a large scale and the concomitant death at an unimaginable scale. In our case, there is an overlap between epidemics and plagues, as both carry and assume the role of spreading of an infectious disease. Taking this view, we can generally define a plague as an infection that is uncontainable, which leads to the mortality of several people. In comparison to our contexts characterised by advanced knowledge in medicine, in the past, we can imagine why any outbreak of an infectious disease ended up becoming an epidemic or plague.

What were the names and nature of the ancient infections? The question may sound easy, but it is an elusive question to historians of medicine. Part of the challenge in defining or labelling ancient diseases is that during biblical times, people used vague terminology to explain and describe illness. For example in Mark 1:29, we are told that Peter's mother-in-law lay sick with fever. The same can be said concerning the skin disease that is labelled as leprosy in the Bible, a description that was used for any kind of change of skin or even changes in the texture of a building wall (Mk 1:40). With reference to the Hippocratic Epidemics, most diagnosis of illnesses was descriptive based on the patient's version and experience of pain or the doctor's observations at a particular time. At best, the conclusions from such descriptions were mostly less precise (Nutton 2012:22). Furthermore, viruses mutate and human beings adapt to various sicknesses over centuries. Thus, a virus that used to be deadly in the past may find the body's immune system much stronger to cause any harm (Nutton 2012:22). As it happens even today, a medical anthropological lens informs us that people carrying infectious diseases were marginalised (Foster 1976:773).

\section{Notable epidemics in Greek and Roman contexts}

To understand the cultural worldview and panic surrounding infections, we illustrate with consequences few plagues that ravaged Greco-Roman cities. Before $330 \mathrm{BCE}$, ancient cities such as Athens, Alexandria, Syracuse, Carthage and Antioch had relatively small populations of about 15000 people (Nutton 2012:22). Villages had much less, with most people concentrated or distributed in the countryside. Later by 10 $\mathrm{CE}$, most Greco-Roman cities witnessed growth in population in major cities such as Carthage, Syracuse, Antioch and Athens - all recording growth rates of above 75000 people, and some even 2 million people (Nutton 2012:19). Even villages such as Capernaum had more than 3000 people with some suggesting a lower figure of 1000 people (Reed 2002:65).

Ancient cities and villages were prone to several factors that brought in deadly infections, mostly attributed to people travelling between cities and villages. Studies show that most ancient cities were very small and survived from the food that was brought from the countryside. Erroneously and agreeing with Moses Finley's 'model of the ancient city as 
consumer city', most scholars describe ancient cities as parasitical, thereby causing tension between cities and the countryside (Reed 2002:67). I am persuaded more by Jonathan Reed and, especially, Vivian Nutton in saying, 'town and countryside were everywhere, intimately connected' (Nutton 2012:9). In return for money or barter trade, people from the countryside would bring their harvest for sale to the city or to the village dwellers. Nutton (2012:9) refers to several instances whereby people from the countryside withheld their crops to create artificial demand and supply, thus increasing the price of the food items. However, in the case of cities such as Rome, where the growing population would threaten civil unrest, the appointed governors who also resided in the cities would institute tax and demand farmers in the countryside to supply food (Nutton 2012:20). I would like to dwell on the argument that the free movement of people in and out from the cities and villages facilitated the outbreak of an infectious disease.

Furthermore, the Roman army travelled long distances to far away posts. It seems that the army camps were prone to deadly infections. Writing in his book 4, circa 259 CE, Paulus Orisius reports a disturbing plague that hit the camp of Himilco - the King of the Carthaginians - whilst on his military expedition against Sicily during the reign of Darius (550 BCE-487 BCE). Orosius (2010) recounts, saying:

[W] hen he was waging war in Sicily, suddenly (he) lost his army by a horrible plague. The plague did not delay. The people fell in groups with the diseases; everyone was seized quickly and presently died, and there was no burial. (p. 130)

Upon return, the villages and cities feared their return as it was associated with the outbreak of certain infections. In the same way, they felt the transportation of slaves for sale from one location to another, such as Carthage to Rome, would spread infectious diseases in the process.

Notably, most ancient cities were constantly vulnerable to infectious disease, which in most cases proved deadly. Where an infectious disease occurred, several people died and the village or city would not be able to defend itself from enemy attack or feed itself. Generally, infections occurred because of poor living conditions and inefficient drainage systems. Most cities were without sophisticated plumbing systems: drinking water was taken from open wells and waste was thrown out to decompose within few meters from human settlement. Amongst them the privileged people used pit latrines, while the rest used bush toilet (Machline \& Machline n.d.). Archaeologists have unearthed evidence of drainage systems whereby human waste was washed away through a canal into an open field (Poehler 2012:95). Unconfirmed studies indicate that some landowners instructed slaves to use human waste as manure to boost crop production (Leyerle 2009:337). However, such a claim is difficult to imagine, given that cities and villages did not have much land to cultivate. Furthermore, whilst peri-urban agriculture in villages such as Capernaum is evident, the Jewish healthcare system forbids human contact with waste and certain animals. Concerning ritual cleanliness within the Jewish healthcare system, no Jews were supposed to live in a city without public baths or close to uncleanliness (Rosner 1995). Furthermore, in the countryside and given the vast unutilised land, people would easily relieve themselves in the forest without further reuse of the human waste. Although the suggestion of the use of human waste for agricultural purposes is contested, because of the lack of proper drainage system, most Greco-Roman cities were fertile ground for infectious diseases.

Consequently, infections ravaged ancient Roman and Greek cities. In 463-462 BCE, Quintus Livius Titus reported a plague that almost wiped away the city of Rome (463-462) (Livius 1896:286). The disease killed several notable generals, equestrians and senators. Amongst its victims were the newly elected consuls - Lucius Aebutius and Publius Servilius. The cause of the pandemic in Rome was overcrowding, because many people ran away from advancing military threat and left the villages and countryside to seek asylum in Rome. Titus reports that the carnage was worse, such that dead bodies decomposed in the streets and the smell was overpowering. Reporting on the carnage by the epidemic, Livy remarks saying:

[A]great disaster was sustained in both the city and countryside, as men and cattle perished indiscriminately. They were also afraid that the plague would result in famine, since many of the farmers were affected by the disease. (Livius 1896:286; Nutton 2012:9)

Almost three decades later, another plague hit the vulnerable city of Athens with deadly results. Thucydides (460-c400 $\mathrm{BCE}$ ), who also succumbed to the epidemic, reports that the plague ravaged Athens for 4 years between $430 \mathrm{BCE}$ and 426 BCE and claimed the life of an Athenian leader Pericles. Unfortunately, the same plague found its way to Rome where it had similar devastating effects. Many people died including city officials. Like the previous plague that happened in Rome in 462 BCE, several bodies lay unburied in the streets (Poole \& Holladay 1979:282). To add to the catastrophe, the agricultural season was adversely affected, and in addition to the plague, people were facing the possibility of death because of hunger. Thucydides (in volume 2, 47-55) recounts, saying:

[T]hough no pestilence of such extent nor any scourge so destructive of human lives is on record anywhere. For neither were physicians able to cope with the disease, since they at first had to treat it without knowing its nature, the mortality among them being greatest because they were most exposed to it, nor did any other human art avail. And the supplications made at sanctuaries, or appeals to oracles and the like, were all futile, and at last men desisted from them, overcome by the calamity. (Connor 1984:343)

Thucydides gives us first-hand information regarding the deadly infection, saying:

[E]pidemic affected first the head, causing burning red eyes, then the respiratory system, then progressed downwards; retching, 
internal heat, diarrhoea, unbearable thirst, despondency, coupled with skin blisters and ulcers were other, accompanying manifestations of the disease. Some, who escaped death, suffered brain damage - loss of memory - or necrosis of extremities (Thuc. II, 47-55). (Coughanowr 1985:152)

Virologists battled to ascertain the nature of the virus or bacteria and suggestions range from (1) 'a type of typhus, (2) smallpox, (3) pneumonic or bubonic plague, or (4) a virus that has since disappeared or become mutant' (Coughanowr 1985:152).

\section{Theorising infection within personalistic healthcare systems}

For fear of infections from travellers, villages and cities operate similar to the metaphor of the human body - that is, inside the city/body is clean, whilst that which is outside is unclean. Thus, Jesus' debate with the religious leaders in Mark 7 gives a clue regarding the cultural conception associated with the Jewish healthcare system: the village or city walls demarcated the ritually clean from that which was unclean and dangerous. This explains why in the gospel narratives, people with leprosy, the demon possessed and those considered ritually unclean where left outside the village or city walls, or outside the domestic space (see Mk 1:21ff., 5:1ff., 6:25ff.).

The Jewish healthcare system described in the Hebrew Bible and in the New Testament falls under the category of personalistic healthcare system. ${ }^{1}$ A personalistic worldview interprets illness from the perspective of the spiritual world. As God is the giver of both health and affliction, sickness within a Jewish worldview indicates punishment for the sins committed. The condition of being sick signifies a period of punishment, exclusion and separateness. It is socially described with similar social metaphors as poverty, solitude and suspicion of being cursed. Taking this perspective, Victor Turner's theory concerning liminality and communitas may assist in revealing the dynamics concerning infection as it intersects with inequality. Turner used the term liminality to explain ritual stage of being separated from the rest of the community. Usually, ritually unclean persons are viewed as unclean and infectious, and their social position is at the margins of the society. For Turner (Turner, Abrahams \& Harris 2017:95), communitas, which may roughly be translated as community, describes the process through which people who share similar and close identity, based on their social status, form alternative kinship bond. In this study, both the term liminality and communitas are crucial in understanding the dynamics of social exclusion, a social tag associated with being infectious and descriptive of an alternate kinship bond within the Jesus household.

1.Medical anthropologists talk of three healthcare systems - firstly, the biomedical healthcare system, which defined sickness through the lens of presene of bacteria healthcare system, which de common in most healthcars systems, is the nacteria or virus. Secondly, and most common in most healthcare systems, is the naturalistic healthcare system which regards the body as a balanced and autonomous entity and sickness is viewed as disturbance to balance. Thirdly, the personalistic worldview that regards illness as a result of the influence from the supernatural world.

\section{Jesus - The infected healer and infectious movement}

I agree with Hector Avalos that, to the extent that the Christian healthcare system provided alternative healing system to those who had been left outside the city walls by the Jewish healthcare system, it had certain practices that were regarded as facilitators of infection, similar to ritual baths at Asclepius' temple (Avalos 1999:47). Taking the above perspective, we meet the gospel narratives at a point where Jesus and his movement already earned the title of being ritually infectious for three reasons: (1) Jesus talked to, touched and embraced the infectious people such as the lepers, (2) the Jesus community were famous for ritually unclean activities such as not washing hands and welcoming outsiders, (3) unlike Judaism, the Jesus movement embarked on evangelism and, because of sharing the tag of infectious given to travellers, they were equally viewed with suspicion.

\section{Early Christian communities and the practice of welcoming outsiders}

The Jewish healthcare system was based on a cultural system that regarded the non-Jews as ritually unclean. Based on this, interaction with the outsiders was minimal, extending the socio-cultural canopy only to the ethnically Jewish people. Literal evidence indicates that one of the challenges with the rise and schism of Christianity was its seemingly unguarded disregard of the Jewish cultural and healthcare system that defines purity as spatially and culturally inside and impure outside. In Mark 7, concerning the story of the Syrophoenician woman, this can be seen as a cultural debate and a social stance by Christianity to redefine ritual and healthcare systems. Traditionally, scholars see the story as breaking Jewish ritual boundaries by having Jesus reaching out to a ritually unclean gentile woman, whose daughter was demonpossessed (Guelich 1989:385). From this perspective whilst the Jewish ritual worldview is acknowledged, the focus is on the social tension or debate within the early church concerning whether to include gentiles into the nascent Christian movement. The phrases that refers to the Jews as children that should be fed first while the gentile are regarded as dog under the table conjures the ethnic tension between Jews and gentiles within early Christianity (Boring 2006:206; Stein 2008:353).

To this study, two important overlapping issues exist in the story. First, the woman is located both outside her ethnicity and that of Jewish identity. Secondly, concerning Jewish healthcare, being an outsider, she could not receive healing. Her ritual impurity is emphasised by her ethnicity and her being outside the village gates of Tyre. As a traveller and geographically dislocated, she was suspect as being a carrier of infectious diseases. Her story and the healing of her daughter reinforce Hector Avalos' remark that 'Christianity represented a radical departure from attested Jewish healthcare approaches, insofar as the socio-religious status of patients was concerned' (Avalos 1999:70). 


\section{Jesus meeting, talking to and touching the infectious}

Concerning the aspect of meeting and welcoming infectious people, according to the Jewish healthcare system, Jesus' modus operandi of talking and touching infectious people was scandalous. Because of their infectious condition, people with infectious diseases such as the lepers, were found outside the village or city gates. Thus, in terms of conception of space, the Jews always regard spaces outside the city or village as unclean, because this is where the unclean people were located. Several passages exist that indicate Jesus as ritually unclean and infectious. With reference to Mark's gospel, the first reference concerning Jesus found outside the village of Capernaum was in Mark 1:40-44 where Jesus met a man with leprosy. The story of Jesus meeting the man with leprosy comes within a string of narratives concerning healing beginning in the synagogue, which was later followed by the healing of the crowd and then healing of Peter's mother-inlaw. Although connected to the previous healing stories by the theme of healing, it does not tell us where Jesus was coming from and how he came to be outside the village. As Robert Guelich rightly indicates that Mark 'found this unit as a separate pericope' and that the story raises 'the traditional motif of Jesus avoiding re-entering the city' (Guelich 1989:72). In the previous discussion, Jesus went out of the village alone to pray, a theme which to a Jewish audience echoes the character of Moses who prayed in the mountains (Mk 1:35). From the perspective of Jewish healthcare, the story addresses or refers more to the ritual purity rules.

Outside the village and in a ritually unclean space, Jesus met a man with leprosy. In the Hebrew Bible, the term 'leprosy' refers to a variety of skin diseases, and the victims were quarantined outside the village or city. Concerning leprosy, Guelich comments that disease was regarded as the worst form of divine punishment, 'a living death whose healing was equivalent to being raised from the dead' (see 2 Ki 5:7) (Guelich 1989:73). Most New Testament scholars go further to interpret the supplication by the man with leprosy and Jesus' response of touching and being close to the victim as signs of mercy and compassion. Interspersing infection and the social variable of poverty, we find out that most diseases that affected the poor were because of their living conditions.

In addition, the story of Jesus meeting the demon-possessed man, a few kilometres outside the village of Gerasene, puts the story within the context of infection and ritual purity (Mk 5:1-20). Like many villages whose sick people are outside its walls, Jesus was supposed to proceed to the village without talking or even getting near the demon-possessed man. Interpreters to the story vary: others view the story as a Midrash while other regard the story as narrative about an exorcism (Collins \& Attridge 2007:264). Literary phrases such as 'from the tombs', 'unclean spirit' and 'swine' indicate the level of ritual impurity, both of the space and of the man (Guelich 1989:281). The reaction of the crowd may suggest fear of infection from outside coming into their village. Upon hearing the news, the villagers 'come out' to see for themselves, and they saw the previously violent and selfmutilating man 'sitting next to Jesus' (5:15). Instead of celebrating in the village, they requested Jesus to go away. Adela Yarbro Collins opines that the villagers were terrified by the power of the healer (v. 15, 17) (Collins \& Attridge 2007:284). In what seemingly looks like a typical western interpretation, without proper understanding of worldviews and healthcare systems of other cultures, most commentaries on the event see the dismissal of Jesus as evidence of his power that was overbearing and unpredictable to the villagers (Beavis 2011:94; Boring 2006:153; France 2002:230; Lane 1974:187; Stein 2008:258).

Taking a medical anthropological lens, the rush by the villagers outside the village walls and their fear in view of the man's previous condition, to have Jesus within the walls, is plausible as a genuine fear from taking the unclean and infectious within the village walls. In this case, fearing and chasing Jesus away was associated with the view and belief that healers are ambivalent characters; whilst they heal, they may even be carriers of infection and unpredictable in the sense that they can cast an evil spell over the villagers or individuals. The belief that healers can cast evil spells, as Jesus did, and interact with dangerous objects is common in many personalistic healthcare systems.

\section{Early Christian missiology and infectious travellers}

Lastly, unlike its parent religion Judaism, from the early days Christianity showed signs of zeal in winning converts. As John Kloppenborg showed in his recent book Christ's Associations: Connecting and Belonging in the Ancient City, Christianity drew and developed connections with people outside the Jewish ethnicity (Kloppenborg 2019:1). Generally, throughout the Greco-Roman world, people were ambivalent to travellers who they largely viewed as carriers of infectious diseases. For example, writing to his son, Cato the Elder (180 BCE), in favour of traditional herbal medicine, described the itinerant Greek, possibly Hippocratic healers, as charlatans (Nutton 2012:15). Vivian Nutton remarks that the cultural absence of interest in studying medicine amongst Latin students is testimony that in Rome, medicine was viewed negatively. As we have seen concerning plagues, similar negative sentiments were associated with transported slaves and the military (Nutton 2012:15).

To this study, the modus operandi of the early Christian movement of travelling and making converts was likely to receive negative reception in many villages and cities. In detailed instructions concerning provisions to carry and what to do during their journey, itinerant preachers of the Jesus movement were even cautioned, 'And if anyone will not receive you or listen to your words, shake off the dust from your feet when you leave that house or town' (Mt 10:14), in anticipation of rejection. Similar warning and possibility of rejection is repeated in the synoptic texts of Mark 6:8 and 
Luke 9:3. Scholars such as Guelich see the instruction as competing with similar practices by Cynic itinerant preachers, but with much severe instruction of not carrying the bread and the beggar's bag (Boring 2006:176; France 2002:250; Guelich 1989:322). In addition, the shaking off of the dust from the foot may have several connotations. For example it may symbolise similar Jewish practice of shaking dust upon return from a gentile territory, or that they had done their part similar to 'washing hands', or as a symbol of judgment as Matthew further states (Boring 2006:176; France 2002:250; Guelich 1989:322). Inspired by ideas from medical anthropology and historical reality concerning migrating slaves and military, it is more plausible to read the rejection in view of fear of infection. Though most Mediterranean cultures encourage hospitality towards strangers, collective fear exists towards travellers that were less known.

\section{Conclusion}

This study uses insights from medical anthropology to argue that in some instances, Christian healthcare was perceived as an infectious movement. As noted, the Mediterranean basin witnessed major outbreaks of infectious diseases, for example, the plague in Rome, the plague in Athens and several other deadly infections. Furthermore, a look into the infrastructure characterised by lack of clean water, poor hygienic practices and lack of proper waste removal systems indicates that villages and cities were favourable climate for infectious diseases. The outbreak of an infectious disease meant that several people and animals would die, resulting in abandoning the settlement for fear of death. This study noted that the early Christian healthcare system associated with touching, welcoming and travelling evangelism may be looked upon as suspect in spreading contagious pathogens. In view of the outbreak of COVID-19, such suspicions, and our modern knowledge about how pathogens spread, give warning against practices that further exacerbate the spread of infectious diseases. In addition, given that the poor are more vulnerable to infection, love, care and empathy towards those more vulnerable is a recommendable Christian praxis.

\section{Acknowledgements}

\section{Competing interests}

The author declares that he has no financial or personal relationship(s) which may have inappropriately influenced him in writing this article.

\section{Author's contributions}

Z.D. is the sole author of this research article.

\section{Ethical consideration}

This article followed all ethical standards for research without direct contact with human or animal subjects.

\section{Funding information}

This research received no specific grant from any funding agency in the public, commercial or not-for-profit sectors.

\section{Data availability}

Data sharing is not applicable to this article as no new data were created or analysed in this study.

\section{Disclaimer}

The views and opinions expressed in this article are those of the author and do not necessarily reflect the official policy or position of any affiliated agency of the author.

\section{References}

Avalos, H., 1999, Health care and the rise of Christianity, Hendrickson Publishers, Peabody, MA.

Beavis, M.A., 2011, Mark, Baker Academic, Grand Rapids, MI.

Boring, M.E., 2006, Mark: A commentary, Westminster John Knox Press, Minneapolis, MN.

Bwire, D., 2020, 'Melinda Gates said she feared coronavirus in Africa would lead to dead being put out in street, as in Ecuador', viewed 20 June 2020, from https:// africacheck.org/fbcheck/melinda-gates-said-she-feared-coronavirus-in-africawould-lead-to-dead-being-put-out-in-street-as-in-ecuador/.

Collins, A.Y. \& Attridge, H.W., 2007, Mark: A commentary, Augsburg Fortress Publishers, Minneapolis, MN.

Connor, W.R., 1984, Thucydides, Princeton University Press, Princeton, NJ.

Coughanowr, E., 1985, 'The plague in Livy and Thucydides', L'Antiquité Classique 54 152-158. https://doi.org/10.3406/antiq.1985.2146

Foster, G.M., 1976, 'Disease etiologies in non-western medical systems', American Anthropologist 78(4), 773-782. https://doi.org/10.1525/aa.1976.78.4.02a00030

France, R.T., 2002, The Gospel of Mark: A commentary on the Greek text, Wm. B. Eerdmans Publishing, Grand Rapids, MI.

Guelich, R.A., 1989, Mark 1-8: 28, Word biblical commentary 34A, Word Books, Waco, TX.

John, T.J. \& Samuel, R., 2000, 'Herd immunity and herd effect: New insights and definitions', European Journal of Epidemiology 16(7), 601-606. https://doi. org/10.1023/A:1007626510002

Kloppenborg, J.S., 2019, Christ's Associations: Connecting and belonging in the ancient city, Yale University Press, New Haven, CT.

Lane, W.L., 1974, The Gospel of Mark, Wm. B. Eerdmans Publishing, Grand Rapids, MI.

Leyerle, B., 2009, 'Refuse, filth, and excrement in the homilies of John Chrysostom', Journal of Late Antiquity 2(2), 337-356. https://doi.org/10.1353/jla.0.0048

Livius, T., 1896, The history of Rome, book 1-5, transl V. Worrier, Hackett Pub, Indianapolis, IN.

Machline, V. \& Machline, C., n.d., Urban sanitation and the use of human waste as manure in Ancient Rome, viewed 08 June 2020, from https://www.researchgate. net/profile/Vera Machline/publication/273440291 URBAN SANITATION AND THE USE OF HUMAN WASTE AS MANURE IN ANCIENT ROME links/5500a36c0 offaee $14 \mathrm{~b} 5 \overline{6} 85 \mathrm{fc} / \mathrm{URBA} \overline{\mathrm{N}}$-SANITATION-AND-THE-USE-OFHUMAN-WASTE-AS-MANURE-IN-ANCIENT-ROME.pdf.

Nutton, V., 2012, Ancient medicine, Routledge, London.

Orosius, P., 2010, The seven books of history against the Pagans, Liverpool University Press, London.

Poehler, E.E., 2012, 'The drainage system at Pompeii: Mechanisms, operation and design', Journal of Roman Archaeology 25, 95-120. https://doi.org/10.1017/ S104775940000115X

Poole, J.C.F. \& Holladay, A.J., 1979, 'Thucydides and the Plague of Athens', The Classical Quarterly 29(2), 282-300. https://doi.org/10.1017/S0009838800035928

Reed, J.L., 2002, Archaeology and the Galilean Jesus: A re-examination of the evidence, A\&C Black, London.

Rosner, F., 1995, Medicine in the Bible and the Talmud: Selections from Classical Jewish Sources, KTAV Publishing House, Inc, New York, NY.

Stein, R.H., 2008, Mark, Baker Academic, Ada Township, MI.

Turner, V., Abrahams, R.D. \& Harris, A., 2017, The ritual process: Structure and antistructure, Routledge, London. 